ISSN : 2087-2461

PENANGGUNG JAWAB Dekan FIKOM Trimanah, M.Si

Sekretaris Fakultas

Dian Marhaeni K, M.Si

Ketua Penyunting Made Dwi Adnjani, M.Si

Sekretaris

Mubarok, M.Si

Bendahara

Parwati, SH

Dewan Penyunting

Edi Ismoyo, M.Si

Drs. Haryoso

Seksi Usaha

Endang Winarsih, S.Sos

Sirkulasi dan Distribusi

Palupi Satwika, Amd.

Alamat Redaksi

Fakultas Ilmu Komunikasi

Universitas Islam

Sultan Agung Semarang

Jl. Raya Kaligawe Km. 4

Po. Box 1054/SM

Semarang 50112

Telp. (024) 6583584

ext. $448 / 449$

Fax. (024) 6582455

email : jurnalfikom@yahoo.com
Konstruksi Teori Komunikasi Dalam Tafsir Al Qur'an Surat Al Fatihah

Mubarok

mubarok@unisula.ac.id

$110-127$

Inovasi Komunikasi Pemasaran Pada RRI Semarang

Agus Triyono

agustriyono7@gmail.com

128-136

Pengaruh Word of Mouth dan Brand Awareness terhadap Intensi Mengunjungi Tempat Wisata Ziarah Makam Sunan Kalijaga Demak

Santi Ratnawati

santirahmawati@ymail.com

$137-148$

Pengaruh Persepsi Downline Tentang Kualitas Jasa Upline Pada Multi Level Marketing Tianshi Terhadap Loyalitas Downline di Malang

(Studi pada jaringan Akhmad Fidzan)

Devi Purnamasari

devi.purnamasari9@g mail.com

149-163

Manajemen Krisis Polri dalam Kasus Penyerangan Lembaga Permasyarakatan Cebongan Sleman Daerah Istimewa Yogyakarta

Iva Anjar Pawestri

iva.anjar89@yahoo.co.id

$164-180$

Identitas Diri Remaja Melalui Status Sosial Facebook

Muna Madrah

munamadrah@unissula.ac.id.

Made Dwi Adnjani

made@unissula.ac.id

$181-198$

Efektifitas Pelaksanaan Kebijakan Joko Widodo dalam Mengentaskan Kemiskinan (Studi Opini Pemegang Kartu Jakarta Sehat dan Kartu Jakarta Pintar di DKI Jakarta)

Indah Suryawati

indahsuryawati_2121@yahoo.com 199-218 


\title{
EFEKTIFITAS PELAKSANAAN KEBIJAKAN JOKO WIDODO DALAM MENGENTASKAN KEMISKINAN (STUDI OPINI PEMEGANG KARTU JAKARTA SEHAT DAN KARTU JAKARTA PINTAR DI DKI JAKARTA)
}

\author{
Oleh : \\ Indah Suryawati \\ Fakultas Ilmu Komunikasi Universitas Budi Luhur Jakarta \\ indahsuryawati_2121@yahoo.com
}

Abstrak

Penelitian ini bertujuan untuk menggambarkan efektifitas pelaksanaan kebijakan Joko Widodo terkait program Kartu Jakarta Sehat (KJS) dan Kartu Jakarta Pintar (KJP). Penelitian ini untuk menjawab pertanyaan bagaimana opini masyarakat miskin di DKI Jakarta terhadap pelaksanaan program KJS dan KJP. Metode penelitian ini adalah deskriptif kualitatif. Pengumpulan data primer melalui wawancara mendalam dan observasi. Sedangkan data sekunder melalui penelusuran dokumen dan studi pustaka. Hasil penelitian ini menjelaskan terdapat tiga kelompok berdasarkan pengalaman informan terhadap pelaksanaan kebijakan pengentasan kemiskinan yang dijalankan Gubernur DKI Jakarta Jokowi.

Kata kunci: efektivitas, opini publik, kebijakan

\section{Abstract}

This study aims to anlyze the effectiveness of Joko Widodo `s policy of Kartu Jakarta Sehat (KJS) and Kartu Jakarta Pintar (KJP) programs. This research is to show public opinion from poor people of Jakarta related with KJS and KJP implementation. This research method is descriptive qualitative. Collection of primary data obtained through in depth interviews of the poor public in Jakarta related KJS and KJP programs. Menawhile, collection of secondary data obtained through documentation of the various media and library research. The conclusion of this research explaining Jokowi s poverty alleviation policies based on the perception of three groups.

\section{Keywords:effectiveness, public opinion, policy}

\section{Pendahuluan}

Figur Joko Widodo selama dua tahun terakhir telah dicitrakan positif secara massif oleh media. Pencitraan itu dimulai saat launching mobil produksi lokal, mobil Esemka. Pencitraan positif terus mengalir hingga akhirnya menghantarkan Joko Widodo (Jokowi) menjadi Gubernur DKI Jakarta, meskipun harus mengalahkan pesaing terberatnya yang notabene seorang incumbent dan asli Jakarta, Fauzi Bowo.

Gaya Jokowi yang antiformalitas, antigagah-gagahan pejabat dan antibasabasi yang tidak perlu (kecuali dalam norma kesantunan Jawa) dianggap sangat pas untuk menyelesaikan permasalahan Jakarta. Selama menjadi Wali Kota Solo, Jokowi lebih banyak turun ke lapangan dan menjadi problem solver. Karena kemampuannya menata Kota Solo, Jokowi dinobatkan sebagai peringkat ketiga Wali Kota Terbaik Dunia dalam pemilihan World Mayor Project 2012 yang diselenggarakan oleh The City Mayors Foundation, yayasan Wali Kota dunia yang berbasis di Inggris. 
Selama setahun kepemimpinan Jokowi sebagai Gubernur DKI Jakarta telah melakukan berbagai kebijakankebijakan terkait penanganan masyarakat miskin di Jakarta. Apa yang menjadi kampanye Jokowi pada saat pilgub sampai terpilih, kemudian mendapatkan porsi yang banyak dari berbagai khalayak untuk diaparesiasi dan dipromosikan, terutama oleh media cetak dan elektronik secara nasional.

\section{Apalagi ketika Jokowi mengawali peran sebagai gubernur dengan mengeluarkan program andalan. Di bidang kesehatan, mengeluarkan Kartu Jakarta Sehat (KJS) yang diluncurkan pertama kali 31 Oktober 2012. Lalu di bidang pendidikan melalui Kartu Jakarta Pintar (KJP) yang diluncurkan pertama kali 1 November 2012. Program KJS dan KJP ini sengaja didesain untuk dapat lebih menjangkau pelayanan dasar warga miskin dan rentan miskin di DKI Jakarta. Sebaran tingkat kemiskinan menurut kabupaten/kota di DKI Jakarta, dapat dilihat pada tabel 1 .}

\section{Tabel 1}

\section{Tingkat Kemiskinan Menurut Kabupaten/Kota (\%) Tahun 2013}

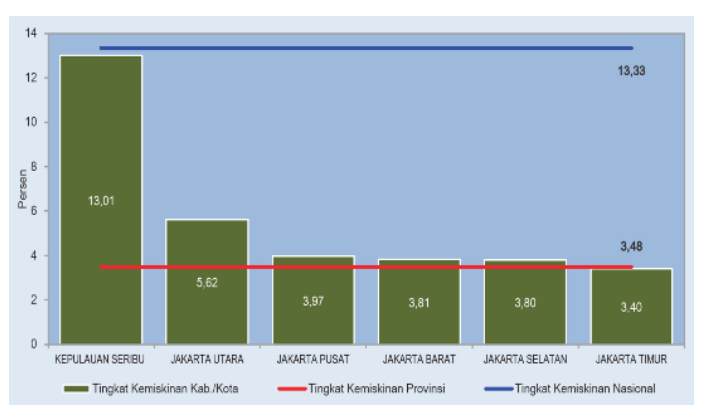

Sumber : Badan Pusat Statistik 2010 dalam TNP2K 2011

Pada tabel 1 di atas, menunjukkan bahwa tingkat kemiskinan tertinggi itu berada di Kepulauan Seribu (13,01 persen), disusul Jakarta Utara (5,62 persen), Jakarta Pusat (3,97 persen), Jakarta Barat (3,81 persen), Jakarta Selatan ( 3,80 persen). Tingkat kemiskinan di wilayah DKI Jakarta ini, semuanya berada di atas tingkat kemiskinan provinsi (3,48 persen). Hanya wilayah Jakarta Timur saja yang tingkat kemiskinannya berada di bawah tingkat kemiskinan provinsi, yakni sebesar 3,40 persen.

Menurut data Badan Pusat Statistik (BPS) Provinsi DKI Jakarta, jumlah penduduk miskin (penduduk dengan pengeluaran per kapita per bulan di bawah Garis Kemiskinan) mencapai 354,19 ribu orang (3,55 persen) pada Maret 2013. Artinya, berkurang 9,01 ribu orang $(0,14$ persen $)$ dibanding penduduk miskin pada Maret 2012 sebesar 363,20 ribu orang (3,69 persen). Jika dibandingkan dengan September 2012, penduduk miskin berkurang sebesar 12,6 ribu orang (0,15 persen) (Sumber: Berita Resmi Statistik, No. 32/07/31/XV, 1 Juli 2013).

Adapun yang berhasil direalisasikan, untuk KJS misalnya, total penerima tahap I (2012) dibagikan 3.000 KJS, tahap II (Mei 2013) dibagikan 1.733.991 KJS dengan total dana $\mathrm{Rp}$ 1,4 triliun (mendapat suntikan dana penyertaan modal pemerintah Rp 200 miliar). Sementara yang ditarget sebagai penerima KJS sebanyak 7,4 juta jiwa (600 ribu jiwa miskin), 3,8 juta jiwa rentan miskin, 300 ribu jiwa hampir miskin. Adapun untuk KJP, total penerimanya tahun ajaran 2012/2013 sebanyak 332.465 siswa dengan total dana Rp 804 miliar. Kemudiam pada tahun ajaran 2013/2014 sebanyak 410.767 siswa (Sumber : Koran KOMPAS, edisi 25 Oktober 2013).

Fenomena tersebut kemudian berdampak pada opini publik yang terbangun. Beberapa survei ataupun riset yang dilaksanakan media massa maupun lembaga lainnya, Jokowi selalu mendapat angka tertinggi. Belum lagi masifnya ekspose media terhadap Jokowi. Bahkan, pemberitaan Jokowi di berbagai media massa juga sangat memengaruhi preferensi publik terhadap Jokowi, selain 
popularitas dan elektabilitas Jokowi.

Hasil survei opini publik yang dilakukan oleh The Indonesian Institute (TII): center for public policy research pada 10 hingga 20 Oktober 2013 lalu misalnya, menemukan bahwa Jokowi adalah nama dan sosok yang paling terekspos media massa menurut responden dalam satu bulan terakhir saat survei dilakukan, dibandingkan nama-nama lain. Tidak hanya di televisi, radio, dan surat kabar. Di media sosial pun, seperti twitter/SMS/facebook, dan sebagainya, nama Jokowi pun berada di bagian teratas. Berdasarkan hasil survei ini, nama Jokowi paling banyak diekspos televisi, yaitu 71,8 persen. Diikuti pemberitaan Jokowi di surat kabar (10,2 persen), radio (5,0 persen), dan media sosial (4,6 persen) (http://www.shnews. co/detile-28212-mengapa-jokowipopuler.html, tanggal 29 november 2013, pukul 15:04 WIB).

Selama ini belum ada hasil riset secara menyeluruh dalam melakukan penelusuran (tracking) terhadap kinerja gubernur DKI Jakarta ini. Sebagian besar survei yang dilakukan oleh lembaga survei dan dipublish oleh media massa maupun media online terkait survei calon presiden. Di mana nama Jokowi selalu menjadi yang terdepan dalam survei tersebut. Banyak kalangan menilai Jokowi sosok yang paling berpeluang memenangkan Pemilu Presiden 2014.

Padahal masyarakat DKI Jakarta pada khususnya dan masyarakat Indonesia belum banyak yang mengetahui sejauhmana pelaksanaan programprogam yang dilaksanakan Jokowi, terutama pelaksanaan program yang terkait dengan pengentasan kemiskinan. Apakah pemberitaan yang dipublikasikan oleh berbagai media benar-benar sesuai fakta atau hanya sekedar pencitraan media? Sebab media punya peran sangat kuat dalam mengkonstruksi realitas sosial tersebut lewat berita.
Menurut Alex Sobur, media adalah alat untuk menyampaikan berita, penilaian, atau gambaran umum tentang banyak hal, media mempunyai kemampuan untuk berperan sebagai institusi yang dapat membentuk opini publik, antara lain, karena media juga dapat berkembang menjadi kelompok penekan atas suatu ide atau gagasan, dan bahkan suatu kepentingan atau citra yang dipresentasikan untuk diletakkan dalam konteks kehidupan yang lebih empiris (2009:31).

Oleh karena itu, penulis tertarik melakukan penelitian terhadap kinerja Jokowi, lebih fokus lagi pada pelaksanaan program-program terkait upaya menurunkan angka kemiskinan di ibukota khususnya melalui pelaksanaan progam KJP dan KJS. Untuk lebih mengarahkan penelitian ini, maka dibuat perumusan masalah dengan fokus pada pertanyaan berikut : bagaimana opini masyarakat miskin di DKI Jakarta terhadap pelaksanaan program KJS dan KJP.

\section{Tinjauan Pustaka}

\subsection{Efektivitas}

Menurut Shadily (1986), efektivitas menunjukan taraf tercapainya suatu tujuan, suatu usaha dapat dikatakan efektif jika usaha itu tercapai tujuannya. Sementara menurut Anwar Arifin, efektivitas adalah bagaimana pun setiap komunikasi yang kita lakukan senantiasa menimbulkan efek yang positif atau negatif (2002:45).

Pendapat lain mengenai efektivitas adalah pemanfaaatan sumber daya dan prasarana dalam jumlah tertentu yang secara sadar ditetapkan sebelumnya untuk menghasilkan sejumlah pekerjaan tepat pada waktunya (Abdurrahman, 2003:93). 


\subsection{Publik}

Menurut Karl Manhein, publik adalah kesatuan banyak yang bukan berdasarkan interaksi perseorangan, tetapi atas dasar reaksi terhadap stimuli yang sama. Dalam publik mereka terintegrasi oleh tujuan yang dipengaruhi oleh stimuli tertentu (Nurudin, 2002).

Sedangkan Herbet Blumer ditambahi oleh Kingley Davis mengatakan bahwa publik itu sekelompok tetapi bukan kesatuan, interaksi dapat terjadi secara tidak langsung melalui alat-alat komunikasi yaitu tingkah laku publik didasari pada tingkah laku individu (Nurudin, 2002).

Publik mempunyai empat tipe yaitu sebagai berikut :

1. All issue publics,bersikap aktif dalam semua isu.

2. Apatheic publics, tidak memerhatikan atau tidak aktif terhadap semua isu.

3. Single issue publics, aktif pada satu atau sejumlah isu terbatas (publik ini termasuk kelompok 'pro kehidupan'kelompok lingkungan dan kelompok hak binatang);

4. Hotissue publics, baru aktif setelah semua media mengekspose hampir semua orang dan isu menjadi topik sosial yang diperbincangkan secara luas (Cutlip\&Center, 2006).

Berdasarkan penjelasan tersebut, maka publik dalam penelitian ini adalah masyarakat miskin maupun rentan miskin yang bermukim di wilayah DKI Jakarta, baik itu warga yang mendapatkan KJS dan KJP maupun warga yang tidak mendapatkan KJS dan KJP.
Mereka ini digolongkan ke dalam publik dengan tipe single issue publics yaitu publik aktif pada satu atau sejumlah isu terbatas, di mana isu yang dimaksud adalah terkait kebijakan Jokowi mengentaskan kemiskinan melalui pelaksanaan program KJS dan KJP.

\subsection{Opini Publik}

Ada banyak definisi tentang opini publik. Istilah ini pertama kali digunakan oleh Machiavelli dalam pengertian yang modern. Dalam bukunya yang berjudul, Discourses, Machiavelli berpesan bahwa orang yang bijaksana tidak akan mengabaikan pendapat umum mengenai soal-soal tertentu.

Menurut Arthur Kornhauser sebagaimana dikutip Bernard Hennessy dalam bukunya berjudul Pendapat Umum, pendapat umum merupakan pandangan dan perasaan yang sedang hidup di kalangan rakyat tertentu pada saat tertentu mengenai suatu isu yang menarik perhatian rakyat (1989:4).

Dalam ungkapan sehari-hari, opini publik sering muncul sebagai istilah yang sangat umum, yang melukiskan sesuatu seperti sikap bersama (collective attitude) atau suasana hati masyarakat (public mood). Lebih jauh lagi, opini publik sering dikaitkan dengan pendapat bahwa setiap orang harus menghormati opini publik. Dalam hal ini, opini publik terbagi menjadi opini publik yang bijaksana dan opini publik yang tidak bijaksana. Ini didasari oleh pendapat para ahli.

Carlyle berpendapat bahwa opini publik adalah kebohongan yang paling besar di dunia. Sementara Lincoln menyebutkan bahwa opini publik pada umumnya didasari oleh rasa keadilan yang kuat. Bila 
dipikirkan sejenak, kita yakin bahwa berbicara tentang opini publik --sebagai kekuatan politik maupun kekuatan sosial yang tak berwujud --- mensyaratkan adanya suatu isu atau berbagai isu. Lincoln agaknya bermaksud bahwa dalam beberapa tahun bila rakyat diberi kesempatan untuk menyatakan pandangan mereka mengenai berbagai isu yang mendapat perhatian masyarakat luas, biasanya mereka akan dapat memilih secara tepat dan bijaksana (1989:4)

\subsection{Program Kartu Jakarta Sehat (KJS)}

Program Kartu Jakarta Sehat (KJS) adalah salah program pemerintah DKI Jakarta dalam pelayanan kesehatan yang bertujuan untuk memberikan pelayanan yang mudah, murah dan berkualitas kepada masyarakat miskin yang merupakan warga DKI Jakarta. Program ini merupakan program unggulan pemprov DKI Jakarta yang memberikan jaminan pelayanan kesehatan yang menitikberatkan pada pelayanan di unit pelayanan khususnya Puskesmas.

Program KJS adalah janji politik Jokowi dan merupakan program unggulan selama kepemimpinannya hingga empat tahun kedepan. Program ini telah dicanangkan oleh pemprov DKI Jakarta sejak bulan November 2012 yang telah dikuatkan dengan Peraturan Gubernur (Pergub) Nomor 187 tahun 2012 tentang Pembebasan Biaya Pelayanan Kesehatan yang telah diubah dengan Peraturan Gubernur Nomor 14 tahun 2013.

Pergub Nomor 187 tahun 2012 tentang Pembebasan Biaya Pelayanan Kesehatan Pasal 6 menyebutkan : masyarakat yang dapat menerima pembebasan biaya pelayanan kesehatan sebagaimana dimaksud dalam Pasal 4 adalah penduduk yang memiliki Kartu Tanda Penduduk Provinsi Daerah Khusus Ibukota Jakarta.

Pergub 187 tahun 2012 telah diubah dengan Pergub Nomor 14 tahun 2013 dengan perubahan pada pasal 6 tentang kriteria penerima pembebasan biaya pelayanan kesehatan yang menyebutkan :

(1.) masyarakat yang dapat menerima pembebasan biaya pelayanan kesehatan sebagaimana dimaksud dalam pasal 4 sebagai berikut : a) penduduk miskin atau rentan dan b) masyarakat yang memperoleh penghargaan atas jasanya.

(2.) Penduduk miskin atau rentan sebagaimana dimaksud pada ayat (1) huruf a meliputi : a) penduduk yang termasuk dalam data kemiskinan pada Badan Pusat Statistik (BPS) Provinsi DKI Jakarta; b) Penduduk miskin atau rentan yang tidak termasuk dalam data kemiskinan BPS Pemprov DKI Jakarta namun mudah terkena dampak dari suatu keadaan dan/atau kebijakan pemerintah dan belum mempunyai jaminan kesehatan; c) penduduk miskin atau rentan berdasarkan hasil verifikasi administrasi dan peninjauan lapangan oleh petugas Dinas Kesehatan; d) penduduk miskin atau rentan dalam pelayanan kesehatan Ambulans Gawat Darurat milik Dinas Kesehatan; e) penghuni panti sosial/rumah singgah di daerah yang memiliki sertifikat kepesertaan yang bersifat 
kolektif dan direkomendasikan oleh Kepala Dinas Sosial; f) korban Kekerasan Dalam Rumah Tangga (KDRT) di daerah; g) korban perdagangan orang (trafficking) di daerah; dan latau; h) korban bencana di daerah.

(3.) Masyarakat yang diberi penghargaan sebagaimana dimaksud pada ayat (1) huruf b, meliputi : a) penduduk lanjut usia (lansia) di daerah; b) anggota Forum Komunikasi Dermawan Darah (Fokuswanda); c) anggota Legiun Veteran Republik Indonesia (LVRI) Propinsi DKI Jakarta; d) kader posyandu dan kader jumantik yang telah mengabdi selama lima tahun; e) tokoh agama di daerah; f) mantan pejabatan di lingkungan Pemerintah Provinsi DKI Jakarta, beserta istri; g) seniman/budayawan didaerah; dan/atau; h) pengurus Lembaga Musyawarah Kelurahan (LMK), Rukun Warga (RW), Rukun Tetangga (RT) di daerah yang masih aktif.

Pasal ini menunjukkan bahwa pembebasan biaya kesehatan di DKI Jakarta tak hanya diperuntukkan bagi masyarakat miskin atau rentan miskin. Namun juga diperuntukkan bagi masyarakat lainnya yang ditetapkan oleh pemerintah daerah.

\subsection{Program Kartu Jakarta Pintar (KJP)}

Program Kartu Jakarta Pintar (KJP) adalah program pemberian bantuan biaya personal pendidikan untuk pemenuhan kebutuhan peserta didik dengan menggunakan kartu. Program ini khusus diperuntukkan bagi anak usia sekolah SD hingga
SMA atau yang sederajat yang berasal dari keluarga yang tidak mampu.

Program ini juga merupakan janji politik Jokowi-Ahok pada pemilihan Gubernur DKI Jakarta yang lalu. Program ini telah dikuatkan dalam Peraturan Gubernur Nomor 190 tahun 2012 tentang pemberian bantuan biaya personal pendidikan SMA dan SMK bagi peserta didik dari keluarga tidak mampu atau miskin melalui KJP.

Program KJP telah menjadi bagian dari kegiatan dari pemprov DKI Jakarta yang ditandai dengan adanya kegiatan ini dalam RPJMD tahun 2013-2017 dan juga telah mendapatkan dukungan anggaran dalam APBD tahun 2013. Di mana pemberian Biaya Personal Siswa Miskin (BPSM) bagi peserta didik SD/SDLB/MI, SMP/SMPLB/MTS, SMA/SMALB/SMK/SMKLB/ MA melalui KJP didasarkan pada perhitungan besaran unit cost per peserta didik per bulan untuk satu tahun anggaran.

Adapun rincian alokasi pemanifaatan dana BPSM sebagai berikut :

1. SD/SDLB/MI sebesar Rp180 ribu ( $\operatorname{Rp} 2.160 .000$ per tahun).

2. SMP/SMPLB/MTs sebesar Rp 210 ribu (Rp. 2.520.000 per tahun).

3. SMA/SMALB/SMK/SMKLB/ MA sebesar Rp240 ribu (Rp. 2.880.000 pertahun).

Pemenuhan unit kebutuhan bagi peserta didik yang memperoleh program BPSM dapat dirinci sebagai berikut: 
Tabel 2

Pemenuhan Unit Kebutuhan Bagi Peserta Didik

Penerima KJP

\begin{tabular}{|c|c|c|c|c|}
\hline \multirow[b]{2}{*}{ No } & \multirow[b]{2}{*}{ Unit Kebutuhan } & \multicolumn{3}{|c|}{ Unit Cost/Tahun/Satuan Pendidikan } \\
\hline & & SD/SDLB/MI & $\begin{array}{c}\text { SMP/SMPLB/ } \\
\text { MTs }\end{array}$ & $\begin{array}{c}\text { SMA/SMALB/ } \\
\text { SMK/SMKLB/ } \\
\text { MA }\end{array}$ \\
\hline 1 & $\begin{array}{l}\text { Transport ke dan } \\
\text { dari Sekolah }\end{array}$ & Rp 900.000,- & Rp 1.200.000,- & Rp 1.320.000,- \\
\hline 2 & $\begin{array}{l}\text { Buku, Alat Tulis, } \\
\text { dan Tas Sekolah }\end{array}$ & $\mathrm{Rp} \quad 400.000,-$ & Rp 450.000,- & Rp 450.000,- \\
\hline 3 & $\begin{array}{l}\text { Baju dan Sepatu } \\
\text { Sekolah }\end{array}$ & Rp 560.000,- & Rp $\quad 560.000$ & Rp 710.000,- \\
\hline 4 & $\begin{array}{l}\text { Tambahan Makan } \\
\text { dan Minum }\end{array}$ & $\operatorname{Rp} \quad 300.000,-$ & Rp 335.000,- & Rp 400.000,- \\
\hline & Jumlah Total & Rp 2.160.000,- & Rp 2.520.000,- & Rp 2.880.000,- \\
\hline
\end{tabular}

Sumber : Data Primer diolah, peneliti, 2013

Pada Tahun Anggaran 2013 untuk program pemberian BPSM, Pemerintah Provinsi DKI Jakarta melalui Anggaran Pendapatan dan Belanja Daerah (APBD) akan mengalokasikan dana sebesar Rp 804.634.560.000,- (delapan ratus empat miliar enam ratus tiga puluh empat juta lima ratus enam puluh ribu rupiah). Anggaran tersebut diperuntukkan bagi 332.465 siswa miskin dari tiga level satuan pendidikan. Selengkapnya bisa dilihat di tabel 2.2 berikut:

Tabel 3

Anggaran yang Dialokasikan Pemprov DKI Jakarta Untuk Program KJP

\begin{tabular}{|c|c|c|c|c|c|}
\hline No & $\begin{array}{c}\text { Kelompok Usia } \\
\text { (Satuan Pendidikan) }\end{array}$ & $\begin{array}{c}\text { Jumlah } \\
\text { Siswa } \\
\text { Miskin }\end{array}$ & $\begin{array}{c}\text { Unit Cost } \\
\text { Per Bulan } \\
\text { (Rp) }\end{array}$ & $\begin{array}{c}\text { Jumlah } \\
\text { Bulan }\end{array}$ & $\begin{array}{c}\text { Jumlah } \\
\text { Anggaran } \\
\text { KJP (Rp) }\end{array}$ \\
\hline 1 & $\begin{array}{c}7-12 \text { Tahun } \\
\text { (Setara SD/SDLB/MI) }\end{array}$ & 170.386 & 180.000 & 12 & 368.033 .760 .000 \\
\hline 2 & $\begin{array}{c}13-15 \text { Tahun } \\
\text { (Setara SMP/SMPLB/MTs) }\end{array}$ & 83.852 & 210.000 & 12 & 211.307 .040 .000 \\
\hline 3 & $\begin{array}{c}16-18 \text { Tahun } \\
\text { (Setara SMA/SMALB/SMK/ } \\
\text { SMKLB/MA) }\end{array}$ & 78.227 & 240.000 & 12 & 225.293 .760 .000 \\
\hline \multicolumn{2}{|c|}{ JUMLAH } & $\mathbf{3 3 2 . 4 6 5}$ & & & $\mathbf{8 0 4 . 6 3 4 . 5 6 0 . 0 0 0}$ \\
\hline
\end{tabular}

Sumber : Data Primer diolah peneliti, 2013 


\subsection{Kategori Miskin}

Kemiskinan adalah keadaan dimana terjadi ketidakmampuan untuk memenuhi kebutuhan dasar seperti makanan, pakaian, tempat berlindung, pendidikan, dan kesehatan. Kemiskinan dapat disebabkan oleh kelangkaan alat pemenuhan kebutuhan dasar, ataupun sulitnya akses terhadap pendidikan dan pekerjaan.

Pendataan Program Perlindungan Sosial (PPLS) Tahun 2011 menyebutkan bahwa orang miskin di Indonesia dapat dibedakan dengan kategori sangat miskin, miskin, hampir miskin, dan rentan miskin. Sementara itu, Badan Pusat Statistik (BPS) mengkategorikan orang miskin di Indonesia menjadi tiga, yaitu miskin, hampir miskin, dan sangat miskin.

BPS mencatat perhitungan kategori orang miskin, yaitu dilakukan dengan mengetahui bagaimana pemenuhan terhadap kebutuhan dasar berupa nasi (makan), karena jika tidak yang bersangkutan akan meninggal. Kemiskinan yang diukur, yakni dengan mengetahui ketidakmampuan seseorang dari sisi ekonomi. Dengan demikian, bisa saja orang miskin itu mendapat bantuan seperti jaminan kesehatan berupa jamkesmas, bantuan subsidi beras murah, bantuan operasional sekolah dan lain-lain. Orang miskin yang penting bisa makan, karena mereka tidak mampu untuk pengeluaran sandang, perumahan, pendidikan dan kesehatan (sumber viva.co.id).

Sedangkan masyarakat rentan miskin adalah orang yang memiliki pekerjaan dan mampu menghidupi dirinya dan keluarga, tetapi tidak mampu membiayai pengobatan di rumah sakit. Sedangkan masyarakat miskin adalah masyarakat yang tidak bisa memenuhi kebutuhan hidupnya. Selain itu, juga tidak mampu membiayai pengobatan rawat jalan dan rawat inap (Sumber : http:// www.solopos.com/ 2012/03/08/ rentan-miskin).

Fenomena kemiskinan di perkotaan, terutama di DKI Jakarta sangat berbeda dibanding dengan daerah lain. Berbagai penelitian menyatakan bahwa kalangan migran termasuk yang relatif besar dapat memengaruhi tingkat kesempatan kerja, sehingga tingkat pengangguran menjadi tinggi. Mereka yang tidak memperoleh pekerjaan di sektor formal pada akhirnya akan memasuki sektor informal atau berusaha apa saja untuk bisa bertahan hidup.

Menurut BPS, warga DKI Jakarta yang berada pada garis kemiskinan adalah mereka yang memiliki pengeluaran per kapita per bulannya kurang dari Rp 400 ribu. Pada 2012, garis kemiskinan sebesar Rp 379.052 per orang per bulannya. Ini meningkat dibandingkan garis kemiskinan pada 2011 sebesar Rp 355.480 per kapita per bulannya.

Selain itu, kemiskinan di DKI Jakarta sering dikaitkan pula dengan kondisi lingkungan tempat tinggal yang tidak layak. Sebagian besar dari mereka hidup di lokasi padat dan kumuh. Kata kumuh biasa digunakan untuk mengidentifikasi kualitas perumahan yang miskin dan kondisi yang tidak sehat. Permukiman kumuh adalah lokasi dengan tingkat kepadatan tinggi yang dicirikan oleh perumahan yang di bawah standar (struktur dan layanan publik) dan kejorokan. Kemiskinan juga dapat menyebabkan lingkungan menjadi semakin kumuh (http://bplhd.jakarta. go.id, diunduh tanggal 20/11/2013 pukul 16:06 WIB). 
Pemerintah provinsi DKI Jakarta telah melakukan berbagai upaya untuk terus mengurangi jumlah dan persentase penduduk miskin. Upaya tersebut antara lain dengan terus menggulirkan berbagai program penanggulangan kemiskinan, seperti program PNPM Mandiri, PPMK, dls. Disamping itu, juga ada program-program penanggulangan kemiskinan yang berasal dari pemerintah pusat seperti beras miskin (raskin). Pada pemerintahan Jokowi-Ahok, bertambah lagi program pengentasan kemiskinan yaitu KJS dan KJP.

\subsection{Kategori Siswa Miskin}

Sebagaimana disebutkan di atas bahwa siswa miskin adalah peserta didik pada jenjang satuan pendidikan sekolah dasar sampai dengan menengah yang secara personal dinyatakan tidak mampu baik secara materi maupun penghasilan orang tuanya yang tidak memadai untuk memenuhi kebutuhan dasar pendidikan. Kebutuhan dasar pendidikan yang dimaksud mencakup : seragam, sepatu, dan tas sekolah, biaya transportasi, makanan serta biaya ekstrakurikuler.

Lebih jauh tentang penerima BPSM, pemerintah Provinsi DKI Jakarta pada Tahun Anggaran 2013 memberikan BPSM bagi peserta didik SD/SDLB/MI, SMP/SMPLB/ MTs, SMA/SMALB/SMK/SMKLB/ MA melalui KJP dengan persyaratan sebagai berikut :

1. Warga DKI Jakarta yang dibuktikan dengan Kartu Keluarga atau surat keterangan lain yang dapat dipertanggung jawabkan.

2. Membuat surat pernyataan tidak mampu/miskin yang diketahui orang tua dan Ketua Rukun Tetangga (RT) setempat.

3. Terdaftar dan masih aktif di salah satu satuan pendidikan di Provinsi DKI Jakarta.

4. Diusulkan oleh sekolah yang telah ditandatangani oleh Kepala Sekolah, Komite Sekolah, dan Kepala Seksi Dikdas/Dikmen Kecamatan setempat yang selanjutnya diajukan ke Suku Dinas/ Dinas Pendidikan setempat.

5. Menandatangani lembar Pakta Integritas yang telah disediakan.

\section{Metode Penelitian}

Metode yang digunakan peneliti dalam penelitian ini adalah metode penelitian deskriptif-kualitatif. Metode penelitian ini merupak an metode yang tepat, karena penelitian ini mencoba untuk mengumpulkan informasi aktual secara rinci yang diperoleh dari data deskriptif, baik berupa data lisan maupun data tertulis dari objek yang diamati. Penelitian deskriptif adalah jenis penelitian yang memberikan gambaran atau uraian atas suatu keadaan sejelas mungkin tanpa ada perlakuan terhadap objek yang diteliti (Kountur, 2004).

Jalaluddin Rakhmat berpendapat bahwa penelitian deskriptif ditujukan untuk :

1. Mengumpulkan informasi aktual secara rinci yang melukiskan gejala yang ada.

2. Mengidentifikasi masalah atau memeriksa kondisi dan praktikpraktik yang berlaku.

3. Membuat perbandingan ayau evaluasi.

4. Menentukan apa yang dilakukan oleh orang lain dalam menghadapi masalah yang sama dan belajar dari pengalaman mereka untuk menetapkan rencana dan keputusan pada waktu yang akan 
datang (Kriyantono, 2006).

Peneliti menyimpulkan bahwa penelitian bersifat deskriptif memberikan penjelasan mengenai keadaan objek yang diteliti tanpa mengubah apa pun dari objek yang diteliti. Penelitian deskriptif bekerja dengan cara menganalisis, memadukan, mengklarifikasi serta mengorganisasikan suatu hasil observasi.

\section{Subjek dan Objek Penelitian}

Subjek penelitian ini adalah warga miskin dan rentan miskin yang bermukim di wilayah DKI Jakarta. Sedangkan objek penelitian ini adalah efektifitas pelaksanaan KJS dan KJP di DKI Jakarta. Informan yang terpilih adalah warga miskin yang mendapatkan KJS dan KJP maupun warga miskin yang tidak mendapatkan KJS dan KJP. Pemilihan informan didasarkan pada hasil observasi lapangan dan informasi dari kelurahan maupun kecamatan. Lebih jauh tentang informan, dalam penelitian kualitatif dimungkinkan pemilihan informan berdasarkan purposive samplingdengan mengutamakan perspektif emik, artinya mementingkan pandangan informan, yakni bagaimana informan memandang dan menafsirkan program pengentasan kemiskinan yang dijalankan J-A, lebih fokus lagi pada pelaksanaan program KJS dan KJP, sesuai pendapatnya.

Sebanyak delapan orang bersedia menjadi informan dan diwawancarai secara mendalam dalam penelitian ini. Mereka adalah :

$\begin{array}{ll}\text { 1. Nama } & : \text { Mr } \\ \text { Umur } & : 50 \text { tahun } \\ \text { Pekerjaan } & \text { : Pencari kembang } \\ \text { Tempat tinggal } & \text { Jalan Al-Mubarok } \\ & \text { IV, Kebayoran Lama, } \\ & \text { Jakarta Selatan. } \\ \text { Keterangan } & :- \text { Sejak } 2002 \text { menjadi } \\ & \text { penduduk DKI Ja- } \\ & \text { karta (11 tahun). }\end{array}$

- Memiliki KTP dan KK

- Mendapatkan KJS

- Mempunyai dua anak, satu anak diantaranya duduk di bangku SMU

2. Nama : Sri

Umur : :36 tahun

Pekerjaan : Buruh cuci

Tempat tinggal: Jalan Peninggaran Barat, RT 14 /RW 11, Kebayoran Lama Utara, Jakarta Selatan.

Keterangan :-Sejak 1993 menjadi penduduk DKI Jakarta (20 tahun).

- Memiliki KTP dan KK

- Mendapatkan KJS

- Mempunyai satu anak yang duduk di bangku SD pemerintah sehingga mendapatkan fasilitas bebas SPP dan buku pelajaran gratis.

3. Nama : DJ

$\begin{array}{ll}\text { Umur } & : 53 \text { tahun } \\ \text { Pekerjaan } & : \text { Satpam }\end{array}$

Tempat tinggal: Jalan Kemajuan, Petukangan Selatan, Jakarta Selatan

Keterangan :- Sejak 1980 menjadi penduduk DKI Jakarta (33 tahun).

- Memiliki KTP dan KK

- Tidak mendapatkan KJS dan KJP

- Mendapatkan asuransi kesehatan dari 

tempat kerja.

- Mempunyai tiga anak, satu anak diantaranya duduk di bangku kuliah.

4. Nama

:Dy

Umur

$:-$

Pekerjaan

:Pemulung

Tempat tinggal: Jalan Pinang Ranti, Rt 02/ Rw 04, Kampung Makassar, Jakarta Pusat

$\begin{aligned} \text { Keterangan } \quad \text { - } & \text { Sejak } 1998 \text { menjadi } \\ & \text { penduduk DKI Ja- } \\ & \text { karta (15 tahun) } \\ - & \text { Tidak memiliki } \\ & \text { KTP dan KK } \\ - & \text { Tidak mendapatkan } \\ & \text { KJS dan KJP } \\ \text { - } & \text { Tidak memiliki } \\ & \text { anak }\end{aligned}$

5. Nama : Ms

Umur :-

Pekerjaan : Pemulung

Tempat tinggal :Gang Mawar, Rt 10/ Rw 02, Kampung

Makassar, Jakarta Pusat

Keterangan :- Tidak memiliki KTP dan KK

- Tidak mendapatkan KJS dan KJP

- Tidak memiliki anak

6. Nama : Ry

Umur :-

Pekerjaan :Pemulung

Tempat tinggal: Gang Mawar, Rt 10/ Rw 02, Kampung Makassar, Jakarta Pusat
Keterangan :- Tidak memiliki KTP dan KK

- Tidak mendapatkan KJS dan KJP

- Tidak memiliki anak

7. Nama $\quad$ :Wd

Umur :-

Pekerjaan :Pemulung

Tempat tinggal: Jalan Kimia, Kelurahan Menteng, Jakarta Pusat.

Keterangan :- Sejak 1965 menjadi penduduk DKI Jakarta (48 tahun)

- Tidak memiliki KTP dan KKidak mendapatkan KJS KJP

- Mempunyai satu anak yang duduk di bangku SD, namun bersekolah di sekolah swasta, sehingga tidak mendapatkan fasilitas bebas SPP dan buku pelajaran gratis .

8. Nama :At

Umur :-

Pekerjaan : Pemulung

Tempat tinggal : Jalan Kimia, Kelurahan Menteng, Jakarta Pusat.

Keterangan :- Tidak memiliki KTP dan KK

- Tidak mendapatkan KJS dan KJP

- Mempunyai satu anak yang duduk di bangku SD. 


\section{Hasil dan Pembahasan}

Di awal peluncurannya, KJS dan KJPdidesainuntukmenjangkau pelayanan dasar masyarakat miskin dan rentan miskin di DKI Jakarta. Gubernur DKI Jokowi di media massa mengungkapkan keinginannya agar tak ada lagi masalah dengan persoalan kesehatan dan pendidikan. Oleh karena itu, Pemprov DKI Jakarta telah mengucurkan anggaran sebesar Rp 2,02 triliun untuk program KJS dan KJP. Walau dilandasi dengan tujuan baik, praktiknya kedua program ini tidak selalu mulus. Sebab program KJS dan KJP selain telah menelan anggaran yang besar, juga melibatkan pihak ketiga, hingga tarik menarik kepentingan politik.

Setahun setelah program KJS dan KJP ini diluncurkan, Jokowi menilai, program ini positif. Indikatornya adalah pertama, 2,2 juta kartu sudah diberikan kepada masyarakat dari 4,7 juta sasaran; kedua, keluhan tentang kesehatan jarang terdengar lagi, berbeda ketika program ini baru diterapkan, hampir setiap hari ada keluhan tentang pelayanan kesehatan.

$\begin{array}{rcr}\text { Hasil } & \text { wawancara } & \text { berdasarkan } \\ \text { pengalaman } & \text { informan } & \text { terhadap } \\ \text { pelaksanaan } & \text { kebijakan } & \text { pengentasan }\end{array}$ kemiskinan yang dijalankan Gubernur DKI Jakarta Jokowi selama setahun masa kepemimpinannya dapat dibagi dalam tiga kelompok yaitu :

\section{a. Kelompok I : Informan yang mendapatkan KJS karena memiliki KTP dan KK}

Dua informan yang memiliki KTP dan KK mengaku tidak kesulitan untuk mendapatkan KJS. $\mathrm{Mr}$ misalnya, mendapatkan KJS ketika mengantarkan suaminya berobat ke Puskesmas Kebayoran Lama. Petugas puskesmas yang memiliki data terkait warga Kebayoran Lama kategori miskin dan rentan miskin memberitahukan bahwa $\mathrm{Mr}$ dianggap layak untuk mendapatkan
KJS. Petugas puskesmas meminta $\mathrm{Mr}$ agar menyerahkan fotocopy KTP dan KK sebagai prasyarat untuk mendapatkan KJS.

Keberuntungan yang sama dialami oleh $\mathrm{Sr}, 36$ tahun. Warga di Peninggaran Barat RT 14/ RW 11, Kebayoran Lama Utara, Jakarta Selatan. Ibu satu anak ini juga mendapatkan KJS karena memiliki KTP dan kartu keluarga. Meskipun fasilitas tersebut belum pernah dipergunakannya, namun ia bersyukur mendapatkan kartu tersebut. Berbedadengan pengalaman $\mathrm{Mr}$, Sr mendapatkan KJS melalui bantuan RT dan RW setempat. Cukup dengan menyerahkan fotocopykartu keluarga dan KTP, petugas RT/RW secara sukarela membantu $\mathrm{Sr}$ untuk mendapatkan KJS.

Kemudahan yang dialami Sr, tidak terlepas dari peran serta RT/RW setempat yang aktif mensosialisasikan program ini, bahkan terbilang aktif pula mendata warganya. Tak heran jika tak ada satu pun warga di RT/RW kediamaan $\mathrm{Sr}$ yang masuk kategori masyarakat miskin luput dari perhatian. Berbeda dengan pengalaman $\mathrm{Mr}$, di mana ia mendapatkan fasilitas KJS bukan dari pihak RT/RW setempat. Dengan kata lain, pihak RT/RW tidak begitu peduli dengan warganya, termasuk tidak turut mensosialisasikan pelaksanaan program KJS ini kepada masyarakat yang membutuhkan.

Waktu itu suami ibu sakit, kulitnya berubah menjadi bersisik. Gara-gara ngambil pisang di kebon dekat kuburan. Sampe di rumah, badannya pada gatel semua. Kulitnya sampe ngelupas gitu, bersisik, kayak kulitular. Supaya gak tambah parah, ibu bawa suami berobat 
ke puskesmas. Saat itu ada petugas puskesmas yang nanyain soal kartu. Karena mereka tahu ibu miskin dan belum dapat, makanya di urusin sama mereka (Hasil wawancara dengan $\mathrm{Mr}$, pencari kembang, November 2013).

Cuma nyerahin fotocopy KK dan KTP doang ke RT. Nunggu seminggu dua minggu kalo ga salah. Tautau sudah ada aja, di kasi ama sekretaris RT. Kartunya di anter ke rumah (Hasil wawancara dengan $\mathrm{Sr}$, buruh cuci, November 2013).

Sementara pengalaman tetangga Sr, sebagaimana dituturkan oleh $\mathrm{Sr}$, pemegang KJS tidak mendapatkan pelayanan yang berbelit-belit untuk menggunakan kartu tersebut di rumah sakit rujukan. Kecuali jika pasien tidak mengantongi surat pengantar dari puskesmas saat ke rumah sakit. Sebab selain memperlihatkan KJS, pihak rumah sakit meminta surat pengantar dari puskesmas.

Ini sangat beralasan karena pihak pemerintah telah menetapkan prosedur tersendiri terkait pelayanan kesehatan kepada masyarakat. Di mana pelayanan kesehatan harus bermula dari puskesmas. Jika membutuhkan penanganan lebih intensif dan menyeluruh, maka pihak puskesmas akan mengeluarkan surat pengantar ke rumah sakit rujukan. Dengan langkah seperti itu, tidak akan terjadi penumpukan pasien di tingkat rumah sakit, karena sudah dapat terlayani di tingkat puskesmas.

Prosedur yang diberlakukan bagi peserta program jaminan kesehatan, termasuk pemegang KJS, telah sejalan dengan Peraturan Gubernur (Pergub) Nomor 187 tahun 2012 tentang Pembebasan Biaya Pelayanan Kesehatan. Dalam pasal 6 disebutkan, masyarakat yang dapat menerima pembebasan biaya pelayanan kesehatan sebagaimana dimaksud dalam Pasal 4 adalah penduduk yang memiliki Kartu Tanda Penduduk Provinsi Daerah Khusus Ibukota Jakarta.

Program KJS merupakan janji politik Jokowi yang kemudian menjadi program unggulan selama kepemimpinannya hingga empat tahun kedepan sebagai gubernur DKI Jakarta. Program ini telah dicanangkan oleh pemprov DKI Jakarta sejak bulan November 2012 yang telah dikuatkan dengan Peraturan Gubernur (Pergub) Nomor 187 tahun 2012 tentang Pembebasan Biaya Pelayanan Kesehatanyang telah diubah dengan Peraturan Gubernur Nomor 14 tahun 2013.

Dengan kata lain, program KJS hanya diperuntukkan bagi warga miskin dan rentan miskin yang resmi tercatat sebagai warga DKI Jakarta. Sebagaimana yang sering dikatakan Jokowi di hadapan media massa pada beberapa kesempatan, bahwa program KJS merupakan program pembebasan biaya pelayanan kesehatan bagi masyarakat miskin yang merupakan warga DKI Jakarta dengan bukti berupa kepemilikan KTP. Ini pun masih ditambah persyaratan lainnya terkait kriteria miskin dan rentan miskin sebagaimana di atur secara detail dalam Peraturan Gubernur Nomor 14 tahun 2013 Pasal 6.

Berdasarkan penuturan $\mathrm{Mr}$ dan $\mathrm{Sr}$ dapat disimpulkan bahwa keduanya adalah warga dengan kategori masyarakat rentan miskin. 
Di mana warga rentan miskin adalah warga yang memiliki pekerjaan dan mampu menghidupi dirinya dan keluarga, tetapi tidak mampu membiayai pengobatan di rumah sakit.

Tak heran Mr dan Sr merasa sangat lega termasuk dalam warga yang mendapatkan KJS. Dengan kata lain, fasilitas KJS yang diterima $\mathrm{Mr}$ dan $\mathrm{Sr}$ sesuai dengan keadaan $\mathrm{Mr}$ dan $\mathrm{Sr}$ yang merupakan masyarakat rentan miskin. Ini sejalan dengan Peraturan Gubernur Nomor 187 Tahun 2012 yang memuat tentang fasilitas pelayanan kesehatan yang dibebaskan, mekanisme dan sarana pembebasan biaya, pembiayaan dan pengendalian dan pelaporan. Peraturan ini diperkuat dengan Peraturan Gubernur Nomor 14 Tahun 2013 yang menetapkan masyarakat miskin atau rentan miskin dan masyarakat yang diberikan penghargaan untuk menerima pembebasan pelayanan biaya kesehatan.

Jelasnya, Peraturan Gubernur Nomor 14 tahun 2013 Pasal 6 ayat (2) menyebutkan masyarakat yang dapat menerima pembebasan biaya pelayanan kesehatan sebagaimana dimaksud dalam pasal 4 adalah antara lain penduduk miskin atau rentan dan masyarakat yang memperoleh penghargaan atas jasanya. Pasal ini menunjukkan bahwa pembebasan biaya kesehatan di DKI Jakarta tak hanya diperuntukkan bagi masyarakat miskin atau rentan miskin, tapi juga diperuntukkan bagi masyarakat lainnya yang ditetapkan oleh pemerintah daerah.

Dalam penelitian ini pula, ditemukan fakta di lapangan di mana peneliti melalui hasil wawancara dengan warga yang bertempat tinggal di Gandaria, Jakarta Selatan, pada
Rabu (15 Januari 2014), menemukan adanya penyelewengan terkait pemberian surat keterangan miskin kepada warga. Saat wawancara, terungkap ada seorang warga yang sebenarnya tidak termasuk masyarakat miskin maupun rentan miskin namun memperoleh surat keterangan miskin. Pemberian surat keterangan miskin ini oleh oknum RT ternyata dipergunakan oleh oknum warga untuk mendapatkan pelayanan di RS Fatmawati. Padahal oknum warga ini sebenarnya telah mengantongi kartu Askes.

Dengan kata lain, pelaksanaan program KJS masih memungkinkan adanya celah bagi oknum RT/RW dan oknum warga untuk memanfaatkan fasilitas ini padahal ia tidak berhak untuk mendapatkan fasilitas tersebut. Di sisi lain, masyarakat miskin dan rentan miskin, ada yang mengalami kesulitan untuk mendapatkan KJS lantaran tidak mendapat perhatian dari pihak RT/RW setempat.

Salah satu peristiwa yang terjadi di RSUP Fatmawati, jelang tahun baru 2014, merupakan contoh di mana warga pemegang KJS mengalami pelayanan yang tidak memuaskan. Sebagaimana dilaporkan Republikaonline dua hari menjelang tahun baru 2014, pihak RSUP Fatmawati saat itu mengalami kekurangan sejumlah obat jenis tertentu yang seharusnya diterima gratis oleh pasien program jaminan kesehatan, termasuk pengguna KJS. Hal ini terjadi akibat distributor obat untuk RS Fatmawati banyak yang libur di akhir tahun. 
b. Kelompok II: Informan yang mendapatkan KJS tapi tidak mendapatkan KJP, padahal memiliki KTP dan KK

Meski Mr dan Sr menerima KJS, tapi mereka tidak mendapatkan fasilitas KJP. Padahal keduanya memiliki anak yang bersekolah. Selain itu, keduanya memiliki kartu keluarga dan KTP serta masuk kategori masyarakat rentan miskin. Jika Mr masih memiliki satu anak yang bersekolah di bangku SMU, Sr pun memiliki satu anak yang duduk di bangku SD negeri di wilayah DKI Jakarta. Sayang, Mr tidak seberuntung Sr. Anak Mr bersekolah di SMU swasta di wilayah DKI Jakarta pula.

Menurut kebijakan Pemprov DKI Jakarta, siswa SD hingga SMP yang bersekolah di sekolah negeri di wilayah DKI Jakarta tidak akan dikenakan biaya SPP dan mendapatkan buku pelajaran gratis. Pemberian fasilitas ini di luar dari Bantuan Operasional Sekolah (BOS) maupun KJP yang diberikan pemerintah pusat dan Pemprov DKI Jakarta untuk membantu masyarakat miskin di bidang pendidikan.

Menurut laporan Harian Kompas (edisi 25 Oktober 2013), jumlah penerima KJP mencapai 332.465 siswa berdasarkan data dari Badan Pusat Statistik DKI Jakarta. Pada tahun ajaran baru 2013/2014, jumlah penerima bertambah menjadi 410.767 siswa. Total dana yang dikeluarkan mencapai Rp 850 miliar.

Berdasarkan hasil observasi peneliti, $\mathrm{Mr}$ tergolong warga yang layak untuk mendapatkan fasilitas KJP. Anak bungsu Mr yang bersekolah di bangku SMU tergolong siswa miskin. Adapun batasan tentang siswa miskin yaitu peserta didik pada jenjang satuan pendidikan sekolah dasar sampai dengan menengah yang secara personal dinyatakan tidak mampu baik secara materi maupun penghasilan orang tuanya yang tidak memadai untuk memenuhi kebutuhan dasar pendidikan. Kebutuhan dasar pendidikan yang dimaksud mencakup : seragam, sepatu, dan tas sekolah, biaya transportasi, makanan serta biaya ekstrakurikuler.

$\begin{array}{ccr}\text { Mengapa } & \text { anak } & \text { tidak } \\ \text { mendapatkan } & \text { KJP } & \text { padahal }\end{array}$
tergolong siswa miskin? Penyebab utamanya karena fasilitas KJP tidak menyentuh siswa miskin yang duduk di bangku sekolah swasta. Siswa yang bersekolah di sekolah swasta dianggap bukan siswa kategori miskin dan rentan miskin. Sayang Mr tidak memberikan jawaban lebih mendalam terkait hal tersebut. Bagi dirinya, anak bungsunya bisa duduk di bangku SMU sudah merupakan kebanggaan. Karena anak tertuanya yang tidak sampai mengecap pendidikan SMU, harus menjalani pekerjaan sebagai penjual rujak keliling. Tak lain untuk membantu suaminya yang sudah puluhan tahun sebagai penjual rujak keliling.

Sedangkan Sr, meski anaknya mendapatkan fasilitas bebas SPP dan pembagian buku pelajaran gratis karena bersekolah di DKI Jakarta, ia tetap berharap bisa mendapatkan fasilitas KJP. Bagi Sr, KJP akan sangat membantu dirinya. Sebagai buruh cuci yang memiliki penghasilan pas-pasan, usaha menyekolahkan anak bukan hal yang mudah. Ia mesti menjadi buruh cuci untuk dua hingga tiga rumah dalam sehari agar bisa menyisihkan uang untuk biaya sekolah anak.

Jika mengacu Peraturan Daerah Nomor 8 Tahun 2006 tentang Sistem Pendidikan dalam pasal 5 ayat 
(1), menyebutkan bahwa "warga masyarakat yang berusia 7 sampai 18 tahun wajib mengikuti pendidikan dasar sampai tamat". Pasal 16 huruf (f) menyebutkan bahwa "pemerintah daerah wajib menyediakan dana guna terselenggaranya wajib belajar 12 tahun khususnya bagi peserta didik dari keluarga tidak mampu dan anak terlantar".

Berdasarkan peraturan daerah tersebut, Dinas Pendidikan Provinsi DKI Jakarta telah melaksanakan rintisan WajibBelajar 12 Tahun(2007) dan selanjutnya pada tahun 2012 telah dicanangkan Wajib Belajar 12 Tahun. Untuk mewujudkan program Wajib Belajar 12 Tahun, Pemerintah Provinsi DKI Jakarta akan menjamin seluruh warga usia sekolah untuk mendapatkan pelayanan pendidikan minimal sampai jenjang pendidikan menengah dengan kebijakan pemberian dana Biaya Operasional Pendidikan (BOP) dan Biaya Personal Siswa Miskin (BPSM) guna membantu mereka agar tetap dapat mengikuti pembelajaran di sekolah dengan baik. Khusus untuk BPSM teknis penyalurannya dilakukan melalui Program KJP, yaituberupa kartu ATM Bank DKI.

Sayang, Sr tidak melakukan penelusuran lebih lanjut ke pihak sekolah. Padahal dengan melampirkan antara lain kartu keluarga, KTP, dan surat keterangan tidak mampu dari pihak kelurahan, $\mathrm{Sr}$ bisa mengajukan fasilitas KJP untuk anaknya. Di mana Pemprov DKI Jakarta siap memberikan dana sebesar Rp 2,1 juta per tahun untuk siswa miskin tingkat SD. Bantuan dana sebesar itu sebenarnya bisa membantu meringankan beban $\mathrm{Sr}$ menyekolahkan anaknya.

Namun fakta yang ditemui di lapangan yang didapatkan peneliti dari informan terkait, tidak semua anak yang tergolong siswa miskin mau mengakui bahwa dirinya tergolong siswa miskin. Bagi mereka, kategori siswa miskin membuat mereka malu dan menjadi minder bergaul dengan teman-teman sekolah. Sehingga informasi dari pihak sekolah terkait persyaratan untuk mendapatkan KJP bagi siswa miskin tidak diteruskan oleh siswa bersangkutan kepada pihak orang tua. Di sisi lain, pihak orang tua dari masyarakat miskin dan rentan miskin tidak mengetahui adanya informasi terkait pemberian KJP oleh Pemprov DKI Jakarta.

c. Kelompok III: Informan yang tidak memiliki KTP dan KK, tidak mendapatkan KJS dan KJP.

Kepemilikan KTP maupun
kartu keluarga merupakan
sebagian dari persyaratan utama
yang mesti dipenuhi warga yang
hendak mendapatkan fasilitas KJS
dan KJP. Sebab KTP dan kartu
keluarga merupakan bukti otentik
seseorang sebagai warga DKI
Jakarta. Sementara program KJS
dan KJP merupakan program untuk
masyarakat miskin dan rentan miskin
di DKI Jakarta.

Hal ini berulang kali disampaikan oleh Jokowipada setiap kesempatan maupun pada saat wawancara dengan media massa. Program KJS dan KJP merupakan kemudahan yang diberikan Pemprov DKI Jakarta bagi warga miskin dan rentan miskin yang resmi tercatat sebagai warga DKI Jakarta. Disamping program pembangunan rumah deret, rumah susun sederhana dan beberapa program lainnya bagi warga miskin. Pemenuhan kebutuhan dasar warga miskin 
seperti kesehatan, pendidikan dan perumahan merupakan bagian dari prioritas pembangunan di bawah kepemimpinan Jokowi.

Sebagian informan yang tidak mendapatkan KJS dan KJP lantaran tidak mengantongi KTP dan kartu keluarga, mengeluhkan hal tersebut sebagai cara yang berbelitbelit untuk mendapatkan fasilitas tersebut. Para informan beranggapan bahwa kondisi ekonomi dan sosial mereka bisa menjadi patokan layak atau tidak layak untuk mendapatkan KJS dan KJP. Bukan berdasarkan kepemilikan KTP dan kartu keluarga DKI Jakarta.

Menurut para informan, tak mudah untuk mendapatkan KTP dan kartu keluarga di DKI Jakarta. Meski secara aturan pengurusan KTP tidak dikenakan biaya sepeser pun, namun kenyataan di lapangan seringkali bertolak belakang. Selain membutuhkan biaya yang besar menurut kemampuan ekonomi mereka, persyaratan berkas pun dianggap sulit untuk dilengkapi oleh mereka. Padahal mereka telah bertahun-tahun hidup di Jakarta, bahkan ada satu informan yang mengaku sejak tahun 1965 pindah ke Jakarta. Sayang, lamanya waktu domisili tersebut tidak disertai kesadaran untuk memiliki atau mengurus surat identitas resmi sebagai warga DKI Jakarta.

Kalo harus punya KTP atau KK dulu ya berbelitbelit. Orang seperti saya ngurus KTP atau KK kan gak mampu. Tapi saya belum pernah bertanya sama pihak kelurahan soal itu (Hasil wawancara dengan At, pemulung, November 2013).

Saya tidak punya KTP, dan tidak ada informasi dari lurah (Hasil wawancara dengan $\mathrm{Wd}$, pemulung, November 2013).

Saya berharap pemerintah lebih memperhatikan kami yang belum memiliki KJS dan KJP. Mungkin karena kami tidak mempunyai KTP. Kami tidak punya cukup uang untuk mengurus KTP. (Hasil wawancara dengan Dy, pemulung, November 2013)

Saya gak dapet KJS dan KJP, karena saya gak punya $K K$ ama KTP (Hasil wawancara dengan Ry, pemulung, November 2013)

Pergub Nomor 187 tahun 2012 tentang Pembebasan Biaya Pelayanan Kesehatan Pasal 6 menyebutkan :

masyarakat yang dapat
menerimarasembebasan
biaya pelayanan kesehatan
sebagaimana dimaksud
dalam Pasal 4 adalah
penduduk yang memiliki
Kartu Tanda Penduduk
Provinsi Daerah Khusus
Ibukota Jakarta.

Meskipun para informan ini tidak mendapatkan fasilitas KJS atau KJP lantaran tidak tercatat secara resmi sebagai penduduk DKI Jakarta, dua informan mengakui bahwa mereka mendapatkan keringanan biaya saat berobat ke puskesmas. Dengan kata lain, Pemprov DKI Jakarta telah memberikan pelayanan kesehatan yang murah di tingkat puskesmas.

Pengalaman Wd dan At menunjukkan bahwa pelayanan kesehatan dengan biaya murah di puskesmas-puskemas di DKI Jakarta sangat membantu masyarakat 
miskin. Meski kedua informan ini tidak memiliki KTP maupun KK, pihak puskesmas tetap memberikan pelayanan kesehatan yang murah tanpa prosedur yang berbelit-belit.

\section{Berdasarkan observasi} peneliti, jumlah puskesmas dengan kategori puskesmas percontohan semakin bertambah dan tersebar di kecamatan-kecamatan di wilayah DKI Jakarta. Bahkan ada beberapa puskesmas kategori percontohan kini telah menerima rawat inap sebagaimana rumah sakit. Selain itu, jumlah dokter dan fasilitas kesehatan di puskesmas percontohan tergolong memadai. Sehingga puskesmas bisa melayani masyarakat lebih banyak lagi, tanpa harus menumpuk di rumah sakit-rumah sakit.

\section{Kesimpulan dan Saran}

\subsection{Kesimpulan}

Secara umum, masyarakat miskin dan rentan miskin di DKI Jakarta yang menjadi informan dalam penelitian ini memberikan sikap positif terhadap program pemprov DKI Jakarta terkait pelayanan kesehatan gratis dalam bentuk KJS. Pengalaman informan yang mendapatkan KJS mengaku tidak mengalami kesulitan untuk mendapatkan kartu tersebut sepanjang memenuhi persyaratan yang telah ditentukan pemprov DKI Jakarta, antara lain kepemilikan KTP dan kartu keluarga.

\section{Sedangkan pengalaman} informan yang tidak mendapatkan KJS mengaku tidak mendapatkan KJS lantaran tidak memiliki KTP dan KK. Bahkan salah seorang dari informan ini, pernah nekat mengurus ke pihak RT/RW meski tidak mengantongi KTP, tapi hasilnya nihil. Khusus informan yang tidak mendapatkan KJS lantaran tidak memiliki KTP dan KK tetap bisa mendapatkan pelayanan kesehatan murah saat memeriksakan kesehatan di puskesmas kecamatan.

Kondisi ini berbeda terkait program biaya operasional pendidikan bagi siswa miskin melalui KJP. Informan yang mendapatkan KJS karena kepemilikan KTP dan kartu keluarga tidak mendapatkan KJP meski mereka memiliki anak yang bersekolah dan merupakan siswa miskin. Apalagi informan yang merupakan warga miskin dan rentan miskin di DKI Jakarta dan tidak memiliki KTP ataupun KK. Meski seluruh informan ini tidak termasuk dalam penerima KJP, para informan tetap memberikan sikap positif terkait program pemprov DKI Jakarta yang memberikan bantuan biaya operasional sekolah bagi siswa dari keluarga miskin maupun rentan miskin.

\subsection{Saran}

Saran Praktis : Pihak Pemprov DKI Jakarta hendaknya meninjau kembali regulasi yang terkait pelaksanaan KJS dan KJP sehingga program ini lebih banyak menjangkau masyarakat miskin dan rentan miskin di wilayah DKI Jakarta. Pasalnya, salah satu persyaratan yang sulit dipenuhi oleh masyarakat miskin dan rentan miskin di DKI Jakarta adalah soal kepemilikan KTP dan kartu keluarga. Meski di awal tahun 2014 lahir kebijakan terkait pengurusan KTP gratis, namun kebijakan tersebut belum disosialisasikan secara merata sehingga masih banyak masyarakat yang belum mengetahui. Apalagi masyarakat miskin dan rentan miskin masih terbatas dalam hal kepemilikan 
media massa, dengan begitu informasi pengurusan KTP gratis yang disampaikan melalui media massa dianggap kurang efektif.

Kualitas pelayanan kesehatan terhadap penerima KJS sebaiknya ditingkatkan dengan harapan masyarakat miskin dan rentan miskin dapat memanfaatkan program ini semaksimal mungkin sebagaimana yang dijanjikan oleh Pemprov DKI Jakarta melalui pergub. Diharapkan kejadian di mana masyarakat pengguna KJS harus mengeluarkan sejumlah uang untuk menutupi biaya obat-obatan tertentu yang kehabisan stok tidak terjadi lagi.

Pelaksanaan program KJP bagi masyarakat miskin dan rentan miskin yang memiliki anak yang bersekolah perlu lebih diefektifkan lagi. Sebab masih ditemui masyarakat miskin dan rentan miskin yang sebenarnya layak untuk mendapatkan KJP malah tidak mendapatkan fasilitas ini. Salah satunya karena masyarakat miskin dan rentan miskin tidak mengetahui secara pasti pengurusan program KJP.

Saran Teoritis : Diharapkan dapat dilakukan penelitian dengan tema serupa yaitu terkait efektivitas pelaksanaan program KJS dan KJP pada masyarakat miskin dan rentan miskin di DKI Jakarta dengan menggunakan teori dan metode yang berbeda. Lebih dari itu, diharapkan pula dapat dilakukan penelitian lanjutan yang menyeluruh terkait efektivitas pelaksanaan program KJS dan KJP pada masyarakat miskin dan rentan miskin di DKI Jakarta.

\section{Daftar Pustaka}

\section{Buku :}

Abdurrahman, Oemi, 1995, Dasar-dasar Public Relations, Bandung: Citra Aditya Bakti.

Arifin, Anwar, 2002, Sebuah Pengantar Ringkas, Jakarta: Rajawali Press.

Hennessy, Bernard, 1989, Pendapat Umum (Edisi Keempat), Jakarta: Erlangga.

Kriyantono, Rachmat, 2007, Teknik Praktis Riset Komunikasi, Jakarta: Kencana Prenada Media Group.

Kountur, Ronny, 2004, Metode Penelitian untuk Penulisan Skripsi dan Tesis, Jakarta: Teruna Grafica Penerbit.

Nurudin, 2002, Komunikasi Propaganda, Bandung: PT Remaja Rosdakarya.

Scott, M. Cutlip et.all, 2008, Public Relations Praktis, Bandung: Widya Padjajaran.

Shadily, 1986. Efektivitas Komunikasi, Bandung: Alfabeta.

Sobur, Alex, 2009, Analisis Teks Media, Bandung: PT Remaja Rosdakarya.

\section{Sumber lain :}

Peraturan Gubernur Pergub No 187 Tahun 2012 tentang Pembebasan Biaya Pelayanan Kesehatan

Pergub No 14 Tahun 2013 tentang Perubahan Atas Peraturan Gubernur Nomor 187 Tahun 2012 Tentang Pembebasan Biaya Pelayanan Kesehatan

Pergub No 190 Tahun 2012 tentang Pemberian Bantuan Biaya Personal Pendidikan Menengah Atas dan Sekolah Menengah Kejuruan Bagi Peserta Didik Dari Keluarga Tidak Mampu/Miskin Melalui Kartu Jakarta Pintar.

Badan Pusat Statistik Provinsi DKI Jakarta, Berita Resmi Statistik, No. 32/07/31/XV, 1 Juli 2013.

Koran KOMPAS, edisi 25 Oktober 2013. 
Republika online

http://www.shnews.co/detile-28212mengapa-jokowi-populer.html.

http://bplhd.jakarta.go.id.

http://m.merdeka.com/jakarta/mengapasuara-betawi-penting-buat-foke-nara. html

http://www.solopos.com/ 2012/03/08/ rentanmiskin

viva.co.id. 


\section{Terima kasih kepada Mitra Bestari}

Berkaitan dengan diterbitkannya Jurnal Ilmiah Komunikasi Makna Fakultas Ilmu Komunikasi Universitas Islam Sultan Agung (UNISSULA) Semarang, maka kami menghaturkan banyak terima kasih kepada para Mitra Bestari yang telah berkenan membantu proses penyuntingan artikel ilmiah Makna sampai layak untuk dipublikasikan. Beberapa Mitra Bestari yang terlibat dalam proses penyuntingan :

1. Prof. Deddy Mulyana, MA., Ph.D dari Universitas Padjajaran (UNPAD) Bandung

2. Dr. Turnomo Rahardjo dari Universitas Diponegoro (UNDIP)

3. Dr. Sunarto dari Universitas Diponegoro (UNDIP)

4. Dra. Prahastiwi, Ph.D dari Universitas Sebelas Maret Surakarta (UNS) 


\section{Indeks Penulis}

Agus Triyono i, 128

Anita Septiani Rosana i, 71

Aska Leonardi i, 15

Devi Purnamasari i, 149

Ica Wulansari i, 36, 48

Indah Suryawati i, 199

Iva Anjar Pawestri i, 164

Made Dwi Adnjani i, 181

Mariko Rizkiansyah i, 36

Mubarok i, 110, 208

Muna Madrah i, 181

Riki Arswendi i, 80

Santi Ratnawati i, 137

Soetomo i, 50

Teddy Dyatmika i, 94

Zein Mufarrih Muktaf i, 1 